\title{
Physiological responses of piau (Leporinus friderici, Bloch 1794) to transportation
}

\author{
Mônica Serra ${ }^{1}$, Carla Patrícia Bejo Wolkers ${ }^{1}$, Márcio Aquio Hoshiba², Elisabeth Criscuolo \\ Urbinati $^{1}$
}

\footnotetext{
${ }^{1}$ Faculdade de Ciências Agrárias e Veterinárias/Centro de Aquicultura, Universidade do Estado de São Paulo (UNESP). Via de Acesso Prof. Paulo Donato Castelane, 14884-900, Jaboticabal, São Paulo, Brasil.

2 Universidade Federal do Pampa, Uruguaiana, Rio Grande do Sul, Brasil.
}

\begin{abstract}
This study evaluated stress indicators of juvenile piau (Leporinus friderici) during and after a 4-hour transportation in order to establish an appropriate transportation protocol for this type of fish. Fish were transported in plastic bags (133.1 g/L) and sampled before loading, during 1, 2, 3 and $4 \mathrm{~h}$ and after transportation (2, 6, 12 and $24 \mathrm{~h})$. Blood samples were analyzed for cortisol and glucose levels, hematocrit, hemoglobin level, number and mean corpuscular volume of erythrocytes. Water $\mathrm{pH}$, dissolved oxygen, temperature and ammonia were monitored before, during and after transportation. No mortality was observed through the experiment. Ammonia levels increased throughout transportation, but the low $\mathrm{pH}$ values kept $\mathrm{NH}_{3}$ in safe levels for fish. Cortisol levels increased within $4 \mathrm{~h}$ of transportation, and returned to control condition $2 \mathrm{~h}$ after arrival. Plasma glucose increased within one hour of transportation, reaching peak value within $4 \mathrm{~h}$ and returning to initial condition $2 \mathrm{~h}$ after arrival. Erythrocyte number and hemoglobin levels showed the lowest levels $2 \mathrm{~h}$ after arrival, and mean corpuscular volume increased during transportation, decreasing at 12 and $24 \mathrm{~h}$ after arrival. Transporting piau is stressful, but fish recover the initial condition in short time, showing tolerance to the changes in the water quality parameters.
\end{abstract}

Key Words: cortisol, fish transport, stress

\section{Introduction}

One of the most critical determinants of the success of fish farming is the delivery of a quality product to final destination. Studies have shown that, during transportation, fish are exposed to different stressful stimuli that may cause adverse physiological responses affecting their welfare (Schreck et al., 1989; Erikson et al., 1997; Iversen et al., 1998; Urbinati et al., 2004; Sulikowski et al., 2006; Fagundes \& Urbinati, 2008).

Transporting live fish in closed systems results in degradation of water quality, because of excretory products, mucus and regurgitated food. Also, several factors can become deleterious agents during transportation, including dissolved oxygen, carbon dioxide, water temperature, $\mathrm{pH}$ and ammonia level (Berka, 1986; Erikson et al., 1997). In aqueous solution, ammonia exists as two chemical species, un-ionized ammonia gas $\left(\mathrm{NH}_{3}\right)$, the most toxic, and the ammonium ion $\left(\mathrm{NH}_{4}+\right)$ (Berka, 1986; Paterson et al., 2003). The toxicity of ammonia is affected by water temperature and $\mathrm{pH}$, with un-ionized ammonia increasing as water temperatures and $\mathrm{pH}$ rise (Emerson et al., 1975; Berka, 1986).
The adverse stimuli produced by the transportation operation have shown to cause increased secretion of catecholamines and cortisol in fish (Robertson et al., 1987; Barton \& Iwama, 1991). This primary stress response can induce a cascade of secondary effects, including metabolic, osmoregulatory and immune disturbances (Barton \& Iwama, 1991; Urbinati et al., 2004). Although mortality as a direct consequence of transport is low, the secondary stress effects are responsible for delayed mortality, caused by osmoregulatory dysfunction and disease (Berka, 1986).

The genus Leporinus has several species of commercial value, and comprises the species piau (Leporinus friderici, Bloch 1794, cited by Garavello \& Britski, 2003), also named piau-três-pintas, whose excellent flesh makes it attractive for consumption despite the numerous spines found in meat (Nomura, 1984).

To evaluate the suitability of any species for farming, stress indicators should be measured during common management practices such as transportation. However, studies to evaluate transportation stress response of $L$. friderici do not exist. This study investigated the transport-induced physiological responses on juveniles of piau during a 4 -h procedure and a $24-\mathrm{h}$ period of recovery. 


\section{Material and Methods}

The studyutilized 106juveniles $(33.2 \pm 10.4 \mathrm{~g} ; 13.4 \pm 1.2 \mathrm{~cm})$ obtained from a commercial supplier. Ten fish were sampled before loading into the polyethylene bags and were considered the control group. Blood was drawn from the caudal vasculature in anesthetized fish (benzocaine, $66 \mathrm{mg} / \mathrm{L}$ ) and dispensed in microtubes with or without anticoagulant (potassium fluoride) to separate plasma and serum.

The packing system involved 10-L polyethylene bags, containing $2 \mathrm{~L}$ of fresh water. Eight fish $(133.1 \mathrm{~g} / \mathrm{L})$ were introduced in each plastic bag in the same density previously used for Brycon cephalus (Urbinati et al., 2004). The polyethylene bags were then squeezed above the water level to expel the air, inflated with oxygen gas, tied with rubber strings and packed in cardboard boxes. Transportation proceeded through paved roads for $4 \mathrm{~h}$, which represents the average transportation time in most parts of the São Paulo State. Hourly, three bags were opened for fish samplings, when four fish of each bag were anesthetized and bled ( $\mathrm{n}=12$ per hour). For one time, sampled bags were closed again, but they were not considered in further samplings. After transportation, fish were transferred to 12 recovery tanks $(100 \mathrm{~L})$ with a continuous flow water system. The water was continuously aerated with compressed air diffused through air stones. Fish were sampled again at 2, 6, 12 and $24 \mathrm{~h}$ in the recovery tanks. Blood samples were obtained from 4 fish of each tank, with 3 tanks sampled each time ( $\mathrm{n}=12$ per hour).

The plasma glucose concentration was measured using an enzymatic glucose assay (kit Labtest, São Paulo, Brazil) and serum cortisol, with radioimmunoassay technique (Coat-A-Count kit, DPC, California, USA). Hematocrit, hemoglobin, number and mean corpuscular volume of erythrocytes were measured in a sample of heparinized blood (Celm, Model CC550, automatic blood cell counter).
The water quality parameters were monitored in the stocking tanks in the commercial supplier, immediately after the opening of the bags ( $n=3$ per hour) and in the recovery tanks ( $\mathrm{n}=3$ per hour). Water temperature and dissolved oxygen concentration (DO) were measured using a YSI 55 oxygen meter, and the water $\mathrm{pH}$, using a YSI $63 \mathrm{pH}$ meter (Yellow Springs Instruments, Yellow Springs, OH, USA). Total ammonia was determined (Nessler reactive), and unionized ammonia was calculated according to Emerson et al. (1975).

Differences among treatments were assessed using oneway ANOVA. Means were compared by Tukey test $(\mathrm{P}<0.05)$. Results are presented as means \pm standard deviation.

\section{Results and Discussion}

During transportation, DO was around $20 \mathrm{mg} / \mathrm{L}$ in the first 3 hours and $12 \mathrm{mg} / \mathrm{L}$ at the end of transportation. Either in stocking tanks or in recovery tanks, DO was above $6.5 \mathrm{mg} / \mathrm{L}$. No mortality was observed through the experiment.

The $\mathrm{pH}$ ranged from 6.76 to 6.93 in stocking tanks and through the transportation process, differing significantly from the values registered in the recovery tanks where $\mathrm{pH}$ ranged from 7.8 to $8(\mathrm{P}<0.0001)$ (Table 1$)$. Water temperature increased throughout the transportation (from $20.8 \pm 0.34$ to $24.2 \pm 0.12{ }^{\circ} \mathrm{C} ; \mathrm{P}<0.0001$ )(Table 1 ). The values in the recovery tanks were higher $\left(27.8-28.0^{\circ} \mathrm{C}\right)$, and did not change until the end of the recovery period. Total ammonia in the stocking tanks was $6.23 \mathrm{mg} / \mathrm{L}$, and increased gradually throughout the transportation, from 2.73 to $7.23 \mathrm{mg} / \mathrm{L}$ $(\mathrm{P}<0.0001)$ (Table 1). During the recovery, with water flowing in the tanks, ammonia levels varied between 0.4 and $0.79 \mathrm{mg} / \mathrm{L}$ $(\mathrm{P}<0.1558) . \mathrm{NH}_{3}$ levels did not alter throughout the experiment and the levels registered were below the $\mathrm{LC}_{50}$ reported for other fish species (from $0.6 \mathrm{mg} / \mathrm{L}$, for rainbow trout Oncorhynchus mykiss, to $2.9 \mathrm{mg} / \mathrm{L}$, for channel catfish Ictalurus punctatus; Tomasso 1994).

Table 1 - Water quality parameters during the transportation of L. friderici in the stocking tanks (control), in the bags (1, 2, 3 and $4 \mathrm{~h}$ of transportation) and in the recovery tanks (2, 6, 12 and $24 \mathrm{~h})$

\begin{tabular}{|c|c|c|c|c|c|}
\hline & & & Water qua & parameters & \\
\hline $\mathrm{Sa}$ & & $\mathrm{pH}$ & Temperature $\left({ }^{\circ} \mathrm{C}\right)$ & Total ammonia $\left(\mathrm{mg}^{-1}\right)$ & $\mathrm{NH}_{3}\left(\mathrm{mg} \mathrm{l}^{-1}\right)$ \\
\hline & & $6.81 \pm 0.08 b$ & $19.6 \pm 0.32 \mathrm{c}$ & $6.63 \pm 0.59 \mathrm{a}$ & $0.016 \pm 0.003$ \\
\hline Transportation & $1 \mathrm{~h}$ & $6.85 \pm 0.08 b$ & $20.8 \pm 0.34 \mathrm{c}$ & $2.73 \pm 0.24 \mathrm{~cd}$ & $0.008 \pm 0.002$ \\
\hline & $2 \mathrm{~h}$ & $6.93 \pm 0.03 b$ & $21.4 \pm 0.35 \mathrm{c}$ & $3.78 \pm 0.68 \mathrm{bc}$ & $0.018 \pm 0.004$ \\
\hline & $3 \mathrm{~h}$ & $6.76 \pm 0.02 b$ & $23.7 \pm 0.63 b$ & $5.27 \pm 0.46 \mathrm{ab}$ & $0.016 \pm 0.002$ \\
\hline & $4 \mathrm{~h}$ & $6.93 \pm 0.11 b$ & $24.2 \pm 0.12 b$ & $7.22 \pm 0.02 \mathrm{a}$ & $0.033 \pm 0.009$ \\
\hline Recovery & $2 \mathrm{~h}$ & $8.06 \pm 0.02 \mathrm{a}$ & $27.9 \pm 0.22 \mathrm{a}$ & $0.59 \pm 0.20 \mathrm{~d}$ & $0.042 \pm 0.013$ \\
\hline & $6 \mathrm{~h}$ & $7.99 \pm 0.07 \mathrm{a}$ & $28.0 \pm 0.19 \mathrm{a}$ & $0.44 \pm 0.02 \mathrm{~d}$ & $0.028 \pm 0.004$ \\
\hline & $12 \mathrm{~h}$ & $7.80 \pm 0.08 \mathrm{a}$ & $28.0 \pm 0.23 \mathrm{a}$ & $0.40 \pm 0.07 \mathrm{~d}$ & $0.018 \pm 0.006$ \\
\hline & $24 \mathrm{~h}$ & $7.92 \pm 0.05 \mathrm{a}$ & $27.8 \pm 0.32 \mathrm{a}$ & $0.79 \pm 0.22 \mathrm{~d}$ & $0.044 \pm 0.013$ \\
\hline
\end{tabular}

Results are given as mean \pm S.E.M. $(\mathrm{n}=3$ ). Means with different letters denote significant differences at $\mathrm{P}<0.05$ (ANOVA). 
In spite of the elevated levels of total ammonia during the transportation, the $\mathrm{pH}$ values contributed to keeping $\mathrm{NH}_{3}$ in acceptable levels for $L$. friderici. The water $\mathrm{pH}$ can influence ammonia toxicity. Low $\mathrm{pH}$ decreases the proportion of the toxic form of ammonia $\left(\mathrm{NH}_{3}\right)$ (Emerson et al., 1975; Berka, 1986). With increasing $\mathrm{CO}_{2}$ production throughout the transportation, fish respiration shifted water $\mathrm{pH}$ towards acidity. The $\mathrm{pH}$ registered during the transportation allowed for the production of small levels of $\mathrm{NH}_{3}(0.008-0.033 \mathrm{mg} / \mathrm{L})$ in a range around the levels recommended by Wedemeyer (1996) to guarantee good health condition for fish (below $0.02 \mathrm{mg} / \mathrm{L})$.

The total ammonia levels verified in this study are in a range related in other studies on fish transport. During the 4-h transportation of juvenile matrinxã (Brycon cephalus), in a density of $125 \mathrm{~g} / \mathrm{L}$, ammonia levels were $5.7 \mathrm{mg} / \mathrm{L}$ and unionized ammonia levels were around $0.006 \mathrm{mg} / \mathrm{L}$ (Urbinati et al., 2004). Fingerlings of silver catfish (Rhamdia quelen) were transported for up to $24 \mathrm{~h}$ at densities of up to $168 \mathrm{~g} / \mathrm{L}$ and the levels of ammonia in the water reached $7.5 \mathrm{mg} / \mathrm{L}$, but the low $\mathrm{pH}$ and temperature kept the $\mathrm{NH}_{3}$ levels in tolerable range for the species (below $0.02 \mathrm{mg} / \mathrm{L}$ ) (Golombieski et al., 2003).

In the present study, levels of cortisol prior to handling and transportation (control) were $108.1 \pm 75.2 \mathrm{ng} / \mathrm{mL}$, and at the end of the operation the fish experienced a significant increase in the average plasma cortisol levels compared with the previous samplings including the control $(78.7 \pm 33.4 ; 83.4 \pm 28.7 ; 76.1 \pm 21.6$ and $239.7 \pm 24.5 \mathrm{ng} / \mathrm{mL}$ at $1,2,3$ and $4 \mathrm{~h}$, respectively $(\mathrm{P}<0.05$, Figure $1 \mathrm{~A})$. Within $2 \mathrm{~h}$ after transportation, cortisol levels were shown to return to the initial levels $(104.3 \pm 32.3 \mathrm{ng} / \mathrm{mL})$. The use of cortisol to evaluate stress levels associated with transportation has been used in many fish species. On the other hand, the short recovery time observed in this study was not described in other species. The cortisol profile of fish subjected to transportation varies among fishes. The recovery of resting plasma cortisol levels after an acute stressor of moderate intensity is normally found within $6 \mathrm{~h}$ (Barton et al., 1980; Pickering \& Pottinger, 1989). However, hauling and transportation seem to result in a longer recovery, more than $24 \mathrm{~h}$ in several species (Nikinmaa et al., 1983; Robertson et al., 1987; Schreck et al., 1989). In Atlantic salmon smolts commercially transported for $4.5 \mathrm{~h}$, plasma cortisol concentrations increased from resting values, with a peak $1 \mathrm{~h}$ after transportation and no recovery within $48 \mathrm{~h}$ (Iversen et al., 1998). Eurasian perch (Perca fluviatilis, L) were subjected to stress by transportation and their cortisol levels increased after the operation, and returned to basal levels between the $7^{\text {th }}$ and the $14^{\text {th }}$ days. The maximum

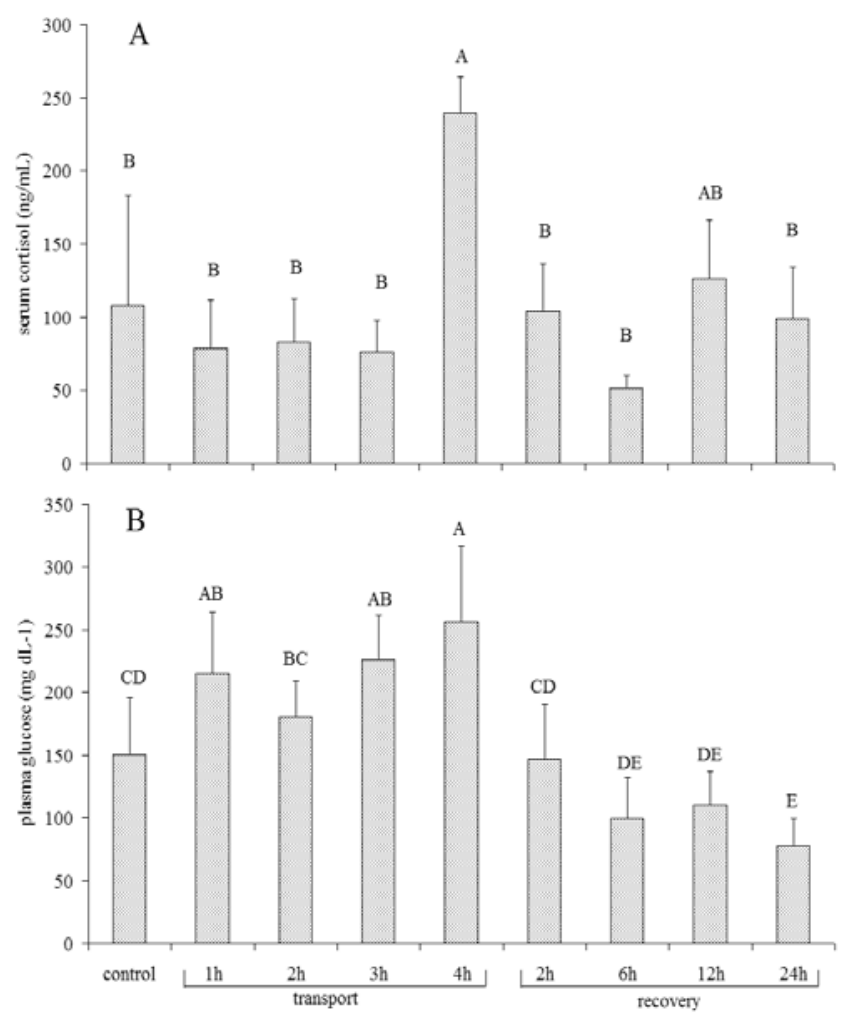

Figure 1 - Serum cortisol (A) and plasma glucose (B) levels during the transportation of $L$. friderici in the stocking tanks (control), in the bags $(1,2,3$ and $4 \mathrm{~h}$ of transportation) and in the recovery tanks $(2,6,12$ and $24 \mathrm{~h})$. The results are given as the mean \pm S.E.M. $(\mathrm{n}=12)$. Bars with different letters denote significant differences at $\mathrm{P}<0.05$ (ANOVA).

cortisol was measured on the $2^{\text {nd }}$ day (Acerete et al., 2004). Adult and juvenile of Brycon cephalus transported for $4 \mathrm{~h}$ showed increased cortisol levels immediately after transport and recovered pre-transport levels within $24 \mathrm{~h}$, although no measurement of the hormone concentrations has been done before that sampling time (Carneiro \& Urbinati, 2001; Urbinati et al., 2004).

During the transportation of L. friderici, cortisol levels had a latency period of $4 \mathrm{~h}$ for the increased response, which may be associated with the highest levels of total ammonia $(7.23 \mathrm{mg} / \mathrm{L})$ and $\mathrm{NH}_{3}(0.033 \mathrm{mg} / \mathrm{L})$ observed in the water transportation at that sampling time, although those levels of un-ionized ammonia are around the levels recommended by Wedemeyer (1996) as safe for fish health. An increase in juvenile pirarucu (Arapaima gigas) cortisol was found $24 \mathrm{~h}$ after transportation, showing a long latency period in their response (Gomes et al., 2006). Contrarily, after 45 and $90 \mathrm{~min}$ of transportation, increased cortisol levels for juvenile winter flounder (Pseudopleuronectes americanus) were observed (Sulikowski et al., 2006). 
Regarding secondary responses, plasma glucose increased significantly in the first hour of transportation compared with the control levels $(214.8 \pm 48.8 \mathrm{mg} / \mathrm{dL}$ and $150.3 \pm 45.5 \mathrm{mg} / \mathrm{dL}$ respectively; $\mathrm{P}<0.0001$; Figure $1 \mathrm{~B}$ ) and the highest mean value was observed at fish arrival $(256.8 \pm 59.8 \mathrm{mg} / \mathrm{dL})$ returning to pre- transportation levels $(146.9 \pm 43.5 \mathrm{mg} / \mathrm{dL})$ within two hours, following the same cortisol profile. Plasma glucose showed the typical catabolic response in $L$. friderici after transportation stress, thus providing extra energy resources, enabling the animal to overcome the disturbance. Alterations in glucose metabolism are a common response to stress in fish (Barton \& Iwama, 1991) also during transportation. The results observed in this study corroborate studies on Brycon cephalus (Urbinati et al., 2004) and Arapaima gigas (Gomes et al., 2006), transported for similar periods of time.

Regarding hematology (Table 2), hematocrit, hemoglobin levels and erythrocyte number did not show important variations through transportation and decreased within two hours of recovery. The mean corpuscular volume (MCV) values showed significant differences from control fish at one and four hours of transportation and the values significantly decreased at 12 and 24 hours of recovery $(\mathrm{P}<0.0001)$. The reduction in hemoglobin levels $(\mathrm{P}<0.0091)$ and erythrocyte number $(\mathrm{P}<0.0006)$ may be attributed to the erythrocytic cell lysis caused by the sudden change of the water $\mathrm{pH}$ when fish were transferred to the recovery tanks after the transport (from 6.93 to 8.06). According to Das et al. (2006), a change in water $\mathrm{pH}$ either due to acidic or alkaline conditions exerted stress in three species of Indian major carps characterized by swelling of erythrocytes, production of immature erythrocytes, and reductions in the total erythrocyte counts and hemoglobin content. The increase in the volume of red blood cells occurs due to the regulatory volume increase mechanism of the cell, which requires an activation of the $\mathrm{Na}^{+} / \mathrm{H}^{+}$with accompanying $\mathrm{Cl}^{-} / \mathrm{HCO}_{3}{ }^{-}$exchanger at the membrane (Weaver et al., 1999).

In the present study, reduction in the erythrocyte number and hemoglobin content indicated a reduced blood oxygen carrying capacity (Jensen, 2003) and also indicated that there was a possibility of respiratory stress in transported L. friderici, although no additional biological changes besides cortisol and glucose were observed.

Table 2 - Hematology during the transportation of L. friderici in the stocking tanks (control), in the bags (1, 2, 3 and $4 \mathrm{~h}$ of transportation) and in the recovery tanks $(2,6,12$ and $24 \mathrm{~h})$

\begin{tabular}{|c|c|c|c|c|c|}
\hline \multirow{2}{*}{\multicolumn{2}{|c|}{ Sampling }} & \multicolumn{4}{|c|}{ Hematology } \\
\hline & & $\mathrm{Ht}(\%)$ & $\operatorname{RBC}\left(10^{6} \mathrm{~mm}^{-3}\right)$ & $\operatorname{MCV}\left(\mu \mathrm{m}^{3}\right)$ & $\mathrm{Hb}\left(\mathrm{g} \mathrm{dL}^{-1}\right)$ \\
\hline \multicolumn{2}{|c|}{ Control } & $41.5 \pm 1.96$ & $2.50 \pm 0.13 \mathrm{abc}$ & $167.1 \pm 3.93 b$ & $14.2 \pm 0.60 \mathrm{ab}$ \\
\hline \multirow[t]{4}{*}{ Transportation } & $1 \mathrm{~h}$ & $48.7 \pm 1.62$ & $2.62 \pm 0.07 \mathrm{abc}$ & $186.2 \pm 3.48 \mathrm{a}$ & $13.6 \pm 0.39 \mathrm{ab}$ \\
\hline & $2 \mathrm{~h}$ & $45.5 \pm 1.80$ & $2.56 \pm 0.07 \mathrm{abc}$ & $177.6 \pm 3.95 \mathrm{ab}$ & $12.9 \pm 0.38 \mathrm{ab}$ \\
\hline & $3 \mathrm{~h}$ & $47.8 \pm 3.40$ & $2.70 \pm 0.19 \mathrm{abc}$ & $177.1 \pm 3.12 \mathrm{ab}$ & $13.9 \pm 0.93 \mathrm{ab}$ \\
\hline & $4 \mathrm{~h}$ & $50.6 \pm 0.97$ & $2.74 \pm 0.05 \mathrm{ab}$ & $188.3 \pm 2.73 \mathrm{a}$ & $14.0 \pm 0.82 \mathrm{ab}$ \\
\hline \multirow[t]{4}{*}{ Recovery } & $2 \mathrm{~h}$ & $38.9 \pm 4.30$ & $2.09 \pm 0.21 \mathrm{c}$ & $173.2 \pm 4.53 \mathrm{ab}$ & $11.7 \pm 1.14 \mathrm{~b}$ \\
\hline & $6 \mathrm{~h}$ & $42.0 \pm 3.24$ & $2.28 \pm 0.15 b c$ & $175.0 \pm 2.12 \mathrm{ab}$ & $12.5 \pm 0.89 \mathrm{ab}$ \\
\hline & $12 \mathrm{~h}$ & $47.7 \pm 2.11$ & $2.93 \pm 0.13 \mathrm{a}$ & $162.7 \pm 2.77 b \mathrm{~b}$ & $16.0 \pm 0.85 \mathrm{a}$ \\
\hline & $24 \mathrm{~h}$ & $45.2 \pm 2.62$ & $2.97 \pm 0.18 \mathrm{a}$ & $148.8 \pm 4.73 \mathrm{c}$ & $15.8 \pm 1.12 \mathrm{a}$ \\
\hline
\end{tabular}

$\mathrm{Ht}$ - hematocrit; RBC - red blood cells; MCV - mean corpuscular volume; Hb - hemoglobin. Results are given as mean \pm S.E.M. $(\mathrm{n}=12)$. Means with different letters denote significant differences at $\mathrm{P}<0.05$ (ANOVA)

\section{Conclusions}

Juvenile L. friderici have a good physiological tolerance and can cope with the stressors imposed by a 4-hour long transportation.

\section{References}

ACERETE, L.; BALASCHA, J.C.; ESPINOSA, E. et al. Physiological responses in Eurasian perch (Perca fluviatilis, L.) subjected to stress by transport and handling. Aquaculture, v.237, p.167-178, 2004.

BARTON, B.A.; IWAMA, G.K. Physiological changes in fish from stress in aquaculture with emphasis on the response and effects of corticosteroids. Review of Fish Diseases, v.1, p.3-26, 1991.
BARTON, B.A.; PETER, R.E.; PAULENCU, C.R. Plasma cortisol levels of fingerling rainbow trout (Salmo gairdneri) at rest and subjected to handling, confinement, transport, and stocking. Canadian Journal of Fisheries and Aquatic Sciences, v. 37 , p.805-811, 1980 .

BERKA R. The transport of live fish. A review. (S.I.): FAO, 1986. p.1-52 (EIFAC Technical Papers, 48).

CARNEIRO, P.C.F.; URBINATI, E.C. Salt as a stress response mitigator of matrinxã during transport. Aquaculture Research, v.32, p.297-304, 2001.

DAS, P.C.; AYYAPPAN, S.; JENA, J.K. Haematological changes in the three Indian major carps, Catla catla (Hamilton), Labeo rohita (Hamilton) and Cirrhinus mrigala (Hamilton) exposed to acidic and alkaline water pH. Aquaculture, v.256, p.80-87, 2006.

EMERSON, K.; RUSSO, R.C.; LUND, R.E. et al. Aqueous ammonia equilibrium calculations: Effect of $\mathrm{pH}$ and temperature. Journal of Fisheries Research Board of Canada, v. 32 , p.2379-2383, 1975. 
ERIKSON, U.; SIGHOLT, T.; SELAND, A. Handling stress and water quality during live transportation and slaughter of Atlantic salmon (Salmo salar). Aquaculture, v.149, p.243-252, 1997.

FAGUNDES, M.; URBINATI, E.C. Stress in pintado (Pseudoplatystoma corruscans) during farming procedures. Aquaculture, v.276, p.112-119, 2008.

GARAVELLO, J.C.; BRITSKI, H.A. Anostomidae (Headstanders). In: REIS, R.E. KULLANDER, S.O.; FERRARIS JÚNIOR, C.J. (Eds.) Checklist of the freshwater fishes of South and Central America. Porto Alegre: EDIPUCRS, 2003. p.71-84.

GOLOMBIESKI, J.I.; SILVA, L.F.V.; BALDISSEROTTO, B. et al. Transport of silver catfish (Rhamdia quelem) fingerlings at different times, load densities, and temperatures. Aquaculture, v.216, p.95-102, 2003.

GOMES, L.C.; CHAGAS, E.C.; BRINN, R.P. et al. Use of salt during transportation of air breathing pirarucu juveniles (Arapaima gigas) in plastic bags. Aquaculture, v.256, p.521-525, 2006.

IVERSEN, M.; FINSTAD, B.; NILSSEN, K.J. Recovery from loading and transport stress in Atlantic salmon (Salmo salar L) smolts. Aquaculture, v.168, p.387-394, 1998.

JENSEN, F.B. Nitrite disrupts multiple physiological functions in aquatic animals. Comparative Biochemistry and Physiology (A), v.135, p.9-24, 2003.

NIKINMAA, M.; SOIVIO, A.; NAKARI, T. et al. Hauling stress in brown trout (Salmo trutta): physiological responses to transport in fresh water or salt water, and recovery in natural brackish water. Aquaculture, v.34, p.93-99, 1983.

NOMURA, H. Dicionário dos peixes do Brasil. Brasília: Editerra, 1984. 482p

PATERSON, B.D.; RIMMER, M.A.; MEIKLE, G.M. et al. Physiological responses of the Asian sea bass, Lates calcarifer to water quality deterioration during simulated live transport: acidosis, red-cell swelling, and levels of ions and ammonia in the plasma. Aquaculture, v.218, p.717-728, 2003.

PICKERING, A.D.; POTTINGER, T.G. Stress responses and disease resistance in salmonid fish: effects of chronic elevation of plasma cortisol. Fish Physiology and Biochemistry, v.7, p.253-258, 1989 .

ROBERTSON, L.; THOMAS, P.; ARNOLD, C.R. Plasma cortisol and secondary stress responses of cultured red drum (Sciaenops ocellatus) to several transportation procedures. Aquaculture, v.68, p.115-130, 1987.

SCHRECK, C.B.; SOLAZZI, M.F.; JOHNSON, S.L. et al. Transportation stress affects performance of coho salmon, Oncorhynchus kisutch. Aquaculture, v.82, p.15-20, 1989.

SULIKOWSKI, J.A.; FAIRCHILD, E.A.; RENNELS, N. et al. The effects of transport density on cortisol levels in juvenile winter flounder, Pseudopleuronectes americanus. Journal of the World Aquaculture Society, v.37, p.107-112, 2006.

TOMASSO, J.R. Toxicity of nitrogenous wastes to aquaculture animals. Reviews in Fisheries Science, v.2, p.291-314, 1994.

URBINATI, E.C.; ABREU, J.S.; CAMARGO, A.C.S. et al. Loading and transport stress of juvenile matrinxã (Brycon cephalus, Characidae) at various densities. Aquaculture, v.229, p.389-400, 2004.

WEAVER, Y.A.; KIESSLING, K.; COSSINS, A.R. Responses of the $\mathrm{Na}^{+} / \mathrm{H}^{+}$exchanger of European flounder red blood cells to hypertonic, $\beta$-adrenergic and acidotic stimuli. Journal of Experimental Biology, v.202, p.21-32, 1999.

WEDEMEYER, G.A. Physiology of fish in intensive culture systems. New York: Chapman \& Hall, 1996. 232p. 